\title{
OPTIMIZATION OF THE SURFACE ROUGHNESS BY APPLYING THE TAGUCHI TECHNIQUE FOR THE TURNING OF STAINLESS STEEL UNDER COOLING CONDITIONS
}

\author{
UPORABA TAGUCHI-JEVE METODE ZA OPTIMIRANJE \\ HRAPAVOSTI POVRŠINE PRI STRUŽENJU NERJAVNEGA JEKLA \\ Z OHLAJANJEM
}

\author{
Murat Sarıkaya \\ Department of Mechanical Engineering, Sinop University, 57030 Sinop, Turkey \\ msarikaya@sinop.edu.tr \\ Prejem rokopisa - received: 2014-11-14; sprejem za objavo - accepted for publication: 2015-01-16
}

doi:10.17222/mit.2014.282

\begin{abstract}
This paper presents the optimization of the surface roughness using the Taguchi technique to assess the machinability of the AISI 316Ti steel with PVD coated carbide inserts under different cooling conditions such as dry, conventional (wet) and cryogenic cooling with liquid nitrogen $\left(\mathrm{LN}_{2}\right)$. Based on the Taguchi $\mathrm{L}_{9}\left(3^{3}\right)$ orthogonal-array design, the machinability tests were made utilizing a CNC lathe machine. Test parameters including the cutting speed, the cooling condition and the feed rate were taken and then the surface roughness $\left(R_{\mathrm{a}}\right)$ was measured to obtain the machinability indicator. An analysis of variance was performed to determine the importance of the input parameters for the surface roughness. The process parameters were optimized by taking the Taguchi technique into consideration. The Taguchi signal-to-noise ratio was employed with the smaller-the-better approach to obtain the best combination. On the basis of the first-order model, a mathematical model was created using the regression analysis to predict the $R_{\mathrm{a}}$ model. The results indicate that the feed rate is the parameter with the highest effect on the surface roughness and that the other parameters also have a statistical significance. In addition, cryogenic cooling is an alternative method for increasing the surface quality of machined parts.

Keywords: AISI 316Ti, cryogenic cooling, machinability, optimization, surface roughness, Taguchi method
\end{abstract}

Članek obravnava optimiranje hrapavosti površine z uporabo Taguchi-jeve metode za oceno obdelovalnosti jekla AISI 316Ti s karbidnimi vložki s PVD-nanosom v različnih razmerah ohlajanja, kot je suho, navadno (mokro) in kriogensko hlajenje s tekočim dušikom $\left(\mathrm{LN}_{2}\right)$. Preizkusi obdelovalnosti so bili izvršeni s CNC-stružnico na osnovi Taguchi-jevega ortogonalnega niza $\mathrm{L}_{9}\left(3^{3}\right)$. Izbrani so bili parametri preizkusov, hitrost rezanja, razmere pri ohlajanju in hitrost podajanja, nato pa je bila izmerjena hrapavost površine $\left(R_{\mathrm{a}}\right)$ kot pokazatelj obdelovalnosti. Izvršene so bile analize variance, da bi ugotovili pomembnost vhodnih parametrov na hrapavost površine. Procesni parametri so bili optimirani z upoštevanjem Taguchi-jeve tehnike. Uporabljeno je bilo Taguchi-jevo razmerje signal - hrup s približkom čim manjše tem boljše za doseganje najboljše kombinacije. Na osnovi modela prvega reda je bil postavljen z uporabo regresijske analize matematični model za napovedovanje $R_{\mathrm{a}}$. Rezultati kažejo, da je hitrost podajanja parameter $z$ največjim učinkom na hrapavost površine, vsi drugi parametri imajo statistično značilnost. Dodatno je kriogensko ohlajanje alternativna metoda za povečanje kvalitete površine struženih delov.

Ključne besede: AISI 316Ti, kriogensko ohlajanje, obdelovalnost, optimizacija, hrapavost površine, Taguchi-jeva metoda

\section{INTRODUCTION}

Stainless steels were developed to obtain a better corrosion resistance compared to traditional carbon steels and they allow us to work at higher temperatures. There is a lot of stainless steel in the industry, but austenitic and ferritic stainless steels are commonly used in the manufacturing industry. ${ }^{1}$ As a type of the AISI 316 steel, austenitic stainless steel AISI 316Ti contains low amounts of titanium (Ti), approximately $0.5 \%$. This steel type has the advantage of enduring higher temperatures for a longer time compared to the other stainless steels. ${ }^{2}$ The physical and mechanical properties of the AISI 316Ti steel are similar to those of the other types of 316 , but the corrosion resistance of $316 \mathrm{Ti}$ is better than those of the standard grades. ${ }^{2}$ In recent years, due to its different properties, this steel has been extensively used for certain applications such as boat and ship parts, medical and chemical handling equipment, heat exchangers, fastening tools, and in nuclear and construction industries where a low thermal conductivity, good heat resistance and corrosion resistance and a high strength are required in the high-temperature working conditions. However, the machining of this austenitic stainless steel is very difficult since it contains a high amount of strength-enhancing elements such as chromium, nickel and molybdenum. ${ }^{1}$ One of the major problems is the heat generation at the cutting region during the machining of difficult-to-cut metals. The machining process requires more energy, so high temperatures occur throughout the deformation process and the friction at the tool-chip and tool-workpiece interfaces. ${ }^{3}$ Recently, the machining technology has been quickly improved to increase the processing productivity and machining performance in the cases of difficult-to-cut steels. An increase in the productivity can be achieved by decreasing the temperature 
at the tool-chip and tool-workpiece interfaces thanks to the cooling/lubrication methods. As the cutting velocity and the feed rate increase during a machining process, due to an improvement in the coating technology, the cutting temperature increases as well. Thus, the use of cooling/lubrication is necessary during the metal-cutting operations. In recent years, certain cooling/lubrication methods such as cryogenic cooling, solid coolants/lubricants, wet cooling (traditional cooling), minimum-quantity lubrication, high-pressure coolants, compressed air/gases have been employed and these technologies have considerably increased the machining productivity. ${ }^{4}$ However, the use of mineral- or syntactic-based cutting fluids has led to certain problems like health risks and environmental pollution. ${ }^{5,6}$ In order to eliminate all the cutting fluids from the metal-cutting process, cryogenic cooling or high-pressure cooling with compressed air can be applied to protect the health and the environment.

Surface roughness is one of the most critical quality indicators of the machined surfaces of engineering materials used for important applications and the producers believe that it determines the degree of surface quality of the manufactured parts. ${ }^{6}$ A low surface roughness obtained from machining experiments contributes to some properties of workpiece including fatigue strength, corrosion and wear resistance, friction, etc. ${ }^{6,7}$ Surface roughness is affected by many parameters such as machined material, depth of cut, cutting-tool material, cutting speed, tool-nose radius, feed rate, coating type and cooling/lubrication conditions. Modern industry aims at producing high-quality parts, reducing the costs in a short time. To manufacture a product with a desired quality of the machining, the optimum process parameters should be chosen. Therefore, recently, certain statistical methods like the Taguchi technique, response-surface methodology (RSM), desirability function analysis, ANOVA and grey relational analysis (GRA) have been implemented to optimize and analyze process parameters. ${ }^{8-12}$ In the engineering applications and academic studies of experimental design, the Taguchi method is very useful thanks to the orthogonal array that significantly reduces the number of the tests and, in addition, it attempts to eliminate the influence of uncontrollable factors on the test results. The main purpose of the Taguchi technique is to provide quality during the design stage. In this way, the cost and the test time decrease in a shorter period. ${ }^{12,13}$ Therefore, in this study, the Taguchi method with the $\mathrm{L}_{9}$ orthogonal array was employed.

In some studies, the machinability of austenitic stainless steel was investigated by the researchers. For example, Kayir et al. ${ }^{1}$ studied the effect of the tool geometry and the cutting parameters on the surface roughness in machining AISI 316Ti under dry cutting conditions. Their results demonstrated that the main parameters were the feed rate with a $73.97 \%$ effect and the radius of the edge with a $13.26 \%$ effect on the surface roughness. Xavior and Adithan ${ }^{14}$ explored the effects of cutting fluids, cutting speed, depth of cut and feed rate on the tool wear and surface roughness in the turning of the AISI 304 austenitic stainless steel using a carbide tool. It was seen that the most important parameter was the feed rate having a $61.54 \%$ effect on the surface roughness, while the cutting speed had a $46.49 \%$ effect on the tool wear. Further, according to the ANOVA analysis, it was found that the cutting fluid had a considerable effect on both the surface roughness and the tool wear. Ciftci ${ }^{15}$ investigated the influence of the cutting speed and the tool coating on the surface roughness and the cutting force in the turning of the AISI 304 and AISI 316 austenitic stainless steels under dry cutting conditions. It was reported that the cutting speed considerably affected the surface roughness. Korkut el al. ${ }^{16}$ determined the best cutting parameters in the turning of the AISI 304 austenitic stainless steel with cemented carbide inserts. Their results showed that the surface roughness decreased with the increasing cutting speed. Tekıner and Yeşılyurt ${ }^{17}$ investigated the influences of the cutting parameters on the basis of the process noise in the turning of the AISI 304 austenitic stainless steel. It was found that the cutting speed of $165 \mathrm{~m} / \mathrm{min}$ and the feed rate of 0.25 $\mathrm{mm} / \mathrm{r}$ gave the best results.

The literature survey indicates that there are very few studies dealing with the turning of the AISI 316 stainless steel. When these studies are examined, it is seen that the surface roughness has not been evaluated with respect to different cutting conditions like dry, wet and cryogenic cooling procedures used during the turning of the AISI 316Ti stainless steel. In the light of the above information, this study can be summarized in three points: Firstly, the influences of the cutting parameters on the surface roughness in the turning of the AISI 316Ti stainless steel with a PVD coated carbide insert were investigated under dry, wet and cryogenic cooling conditions. Secondly, a mathematical model was formed to estimate the result of different levels of input parameters using a regression analysis. In the next process, an analysis of variance (ANOVA) was applied to determine the influences of the machining parameters. Lastly, the process parameters were optimized using the Taguchi technique. To achieve its goals, this paper employed a Taguchi $\mathrm{L}_{9}$

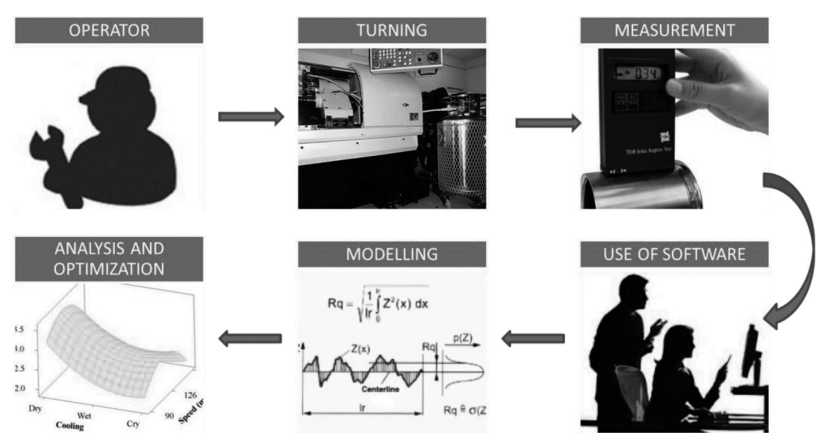

Figure 1: General flow diagram of the study Slika 1: Prikaz poteka študije 
$\left(3^{3}\right)$ orthogonal array for planning the experiments. An experimental design including three parameters (feed rate, cutting speed and cooling condition) with three levels was organized.

\section{EXPERIMENTAL PROCEDURE}

The workflow diagram of this study is illustrated in Figure 1. It shows the sequence of the performed study.

Table 1: Chemical composition of the material in mass fractions, $w / \%$ Tabela 1: Kemijska sestava materiala v masnih deležih, w/\%

\begin{tabular}{|c|c|c|c|c|c|c|c|c|c|}
\hline $\mathrm{C}$ & $\mathrm{Mn}$ & $\mathrm{Si}$ & $\mathrm{P}$ & $\mathrm{S}$ & $\mathrm{Cr}$ & $\mathrm{Ni}$ & $\mathrm{Mo}$ & $\mathrm{Cu}$ & $\mathrm{Ti}$ \\
\hline 0.02 & 1.775 & 0.95 & 0.036 & 0.019 & 16.74 & 10.9 & 2.15 & 0.536 & 0.318 \\
\hline
\end{tabular}
\begin{tabular}{|l|l|l|l|l|l|l|l|l|l|}
\hline 0.021 & 1.775 & 0.495 & 0.036 & 0.019 & 16.74 & 10.92 & 2.15 & 0.536 & 0.318 \\
\hline
\end{tabular}

\subsection{Material, machine tool, cutting tool and measure- ment}

The AISI 316Ti workpiece material was used in the turning experiments and its chemical composition is given in Table 1. Recently, because of its unique properties including good heat resistance and corrosion resistance, a low thermal conductivity and a high strength at higher temperatures, this material has been used in many engineering operations involving boat and ship parts, medical and chemical handling equipment, heat exchangers, fastening tools, and in the nuclear and construction industry. The dimensions of the test material were $\varnothing 60 \mathrm{~mm} \times 200 \mathrm{~mm}$. All the turning tests were conducted using a Falco Fl-8 model (Taiwan) CNC lathe machine with the maximum spindle speed of $4800 \mathrm{r} / \mathrm{min}$ and a $15 \mathrm{~kW}$ drive motor. An assembly produced by Sandvik including a PVD coated carbide insert of type SNMG 1204 08-QM and a PSBNR 2020K-12 tool holder was utilized as the main tool arrangement with the following tool geometry: a rake angle of $-6^{\circ}$, a clearance angle of $0^{\circ}$, the major cutting-edge angle of $75^{\circ}$, a cutting-edge inclination angle of $-6^{\circ}$ and a nose radius of $0.8 \mathrm{~mm}$. The same type of cutting insert was employed for each test parameter. In engineering applications, surface quality is one of the most important quality indicators. For this reason, the average value of the surface roughness $\left(R_{\mathrm{a}}\right)$ was measured using a TIME TR 100 profilometer tester. Before the measurements of the surface roughness, the measuring device was calibrated with a special calibration. Each surface was machined by using a new cutting insert and after each test measurements were carried out on the workpiece.

\subsection{Cutting conditions and design of the experiments}

The cutting speed $\left(V_{\mathrm{c}}\right)$, the feed rate $(f)$ and the cooling condition (C) were taken as the cutting parameters. The values of the cutting parameters were chosen from the plot experiments and the manufacturer's handbook. During the machining tests, a constant depth of cut $\left(a_{\mathrm{p}}=\right.$ $1.6 \mathrm{~mm}$ ) was used; the other cutting parameters and their levels are given in Table 2 . In this study, on the basis of the control factors and their levels from Table 2, the Taguchi $\mathrm{L}_{9}$ orthogonal array (OA) from the Minitab software was used, as shown in Table 3 indicating the design of the experiments. It has nine rows and three columns. The rows correspond to the number of the tests; the columns correspond to the process parameters with three levels. In this array, the first, second and third columns represent the cutting speed, feed rate and cutting condition, respectively. The tests were conducted under different cutting conditions such as dry cutting, conventional wet cooling (flood coolant) and cryogenic cooling inside the tool with liquid nitrogen $\left(\mathrm{LN}_{2}\right)$. For wet cooling, a solution with boron oil and water (the ratio of boron oil $/$ water $=1 / 20$ ) was prepared.

Table 2: Process parameters and their levels

Tabela 2: Procesni parametri in njihovi nivoji

\begin{tabular}{|c|l|c|c|c|c|}
\hline \multirow{2}{*}{ Code } & \multirow{2}{*}{$\begin{array}{c}\text { Control } \\
\text { parameter }\end{array}$} & \multirow{2}{*}{ Notation } & \multicolumn{3}{|c|}{ Levels of factors } \\
\cline { 4 - 6 } A & $\begin{array}{l}\text { Cooling } \\
\text { condition }\end{array}$ & C & Devel 1 & Level 2 & Level 3 \\
\hline B & Feed rate & $f /(\mathrm{mm} / \mathrm{r})$ & 0.1 & Wet & Cryogenic \\
\hline C & $\begin{array}{l}\text { Cutting } \\
\text { Speed }\end{array}$ & $\begin{array}{c}V_{\mathrm{c} l} \\
(\mathrm{~m} / \mathrm{min})\end{array}$ & 90 & 126 & 176 \\
\hline
\end{tabular}

Table 3: Experimental design

Tabela 3: Načrt eksperimentov

\begin{tabular}{|c|c|c|c|c|c|c|}
\hline \multirow{2}{*}{$\begin{array}{c}\text { Exp. } \\
\text { no. }\end{array}$} & \multicolumn{3}{|c|}{ Coded values } & \multicolumn{3}{c|}{ Actual values } \\
\cline { 2 - 7 } & $\mathrm{A}$ & $\mathrm{B}$ & $\mathrm{C}$ & $\mathrm{C}$ & $f /(\mathrm{mm} / \mathrm{r})$ & $V_{\mathrm{c}} /(\mathrm{m} / \mathrm{min})$ \\
\hline 1 & 1 & 1 & 1 & Dry & 0.1 & 90 \\
\hline 2 & 1 & 2 & 2 & Dry & 0.16 & 126 \\
\hline 3 & 1 & 3 & 3 & Dry & 0.25 & 176 \\
\hline 4 & 2 & 1 & 2 & Wet & 0.1 & 126 \\
\hline 5 & 2 & 2 & 3 & Wet & 0.16 & 176 \\
\hline 6 & 2 & 3 & 1 & Wet & 0.25 & 90 \\
\hline 7 & 3 & 1 & 3 & Cryogenic & 0.1 & 176 \\
\hline 8 & 3 & 2 & 1 & Cryogenic & 0.16 & 90 \\
\hline 9 & 3 & 3 & 2 & Cryogenic & 0.25 & 126 \\
\hline
\end{tabular}

For the cryogenic cooling, liquid nitrogen was delivered directly from the liquid-nitrogen pressure tank to the tool holder at a pressure of 1.5 bar as shown in Figure 2. Three holes were drilled into the tool holder. The diameter of the first hole on the tool holder was 6 $\mathrm{mm}$ and it provided a connection between the tool holder

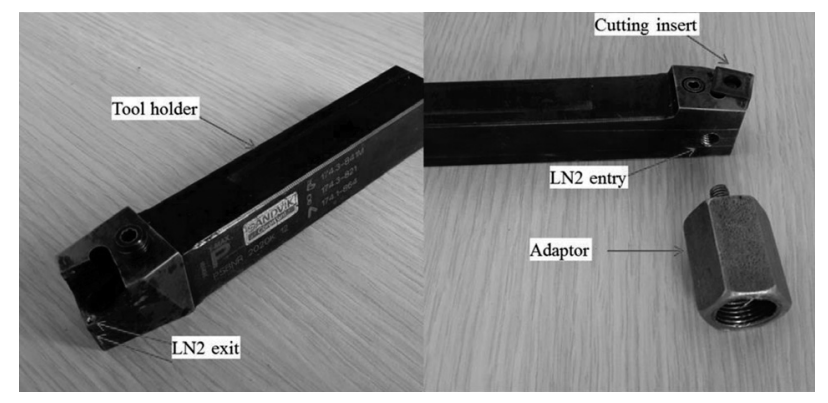

Figure 2: Modified tool holder and adaptor

Slika 2: Prirejen nosilec orodja in adapter 


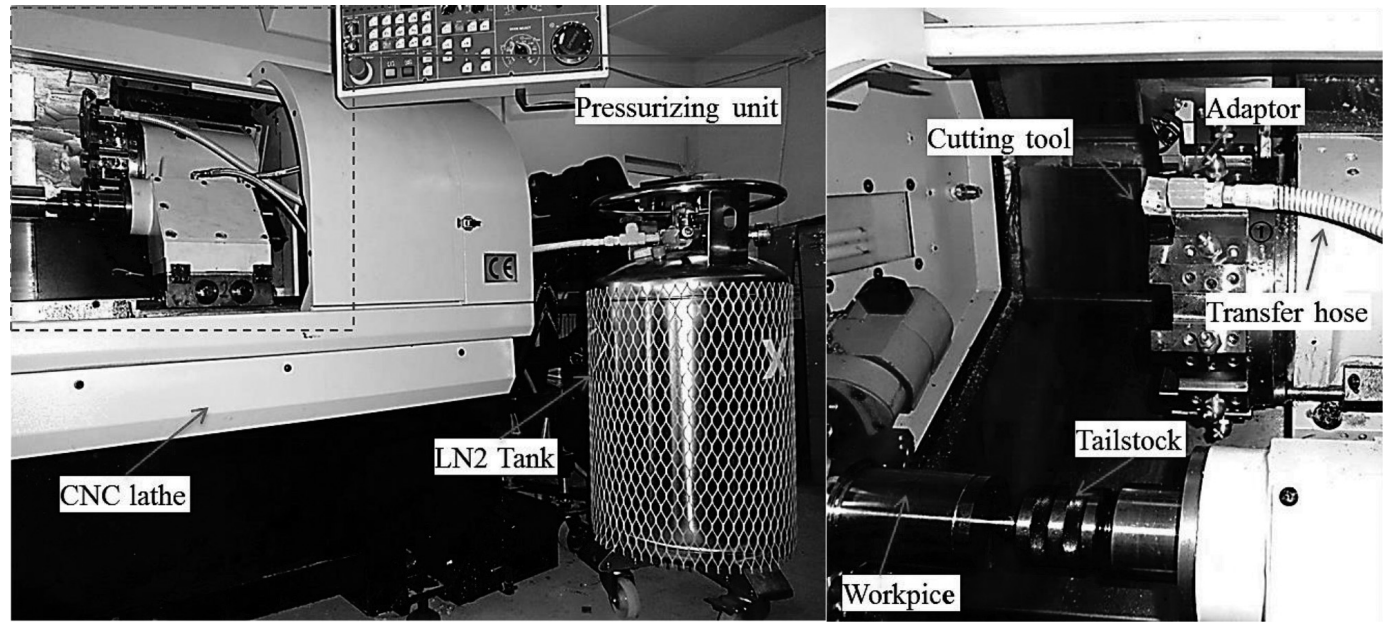

Figure 3: Experimental set-up

Slika 3: Eksperimentalni sestav

and the liquid-nitrogen container with the help of a hose and an adaptor. The liquid nitrogen accumulated inside the tool holder was released to the environment as a gas vapor with the help of the other two holes, taking the heat from the insert. The diameter of the gas exit holes was made to be $1.5 \mathrm{~mm}$. The modified tool holder and the connection adapter are seen in Figure 2, while Figure 3 shows the experimental set-up for cryogenic cooling.

\section{RESULTS AND DISCUSSION}

\subsection{Analysis of the experimental results}

Surface roughness is one of the most important quality criteria for engineering materials. During the turning operations, the surface roughness can be controlled with the machining parameters. In this study, the surface roughness was evaluated using $3 \mathrm{D}$ surface plots in the graphs given in Figure 4. This figure shows that the surface roughness increased significantly with the increasing feed rate. The reason for this can be the fact that an

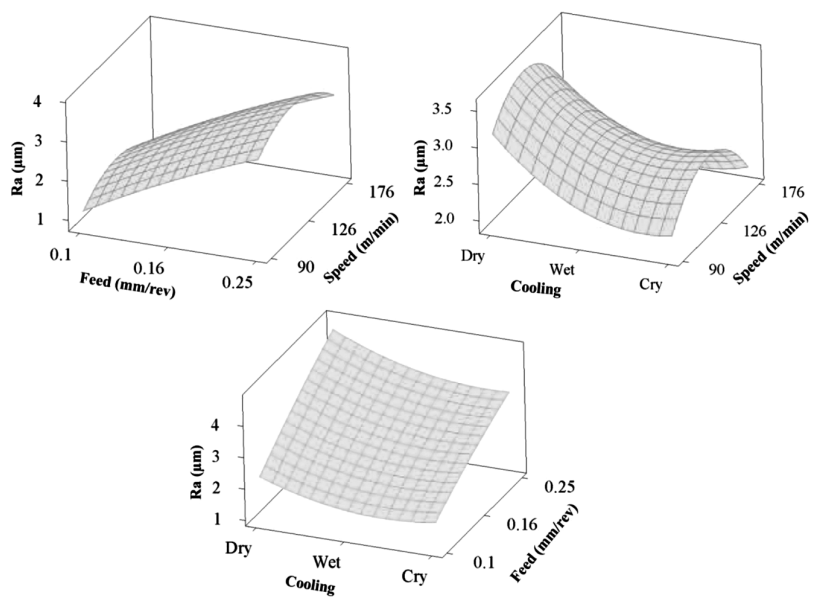

Figure 4: Effects of machining parameters on the surface roughness Slika 4: Vpliv parametrov obdelave na hrapavost površine increase in the feed rate leads to a vibration and increases the heat at the tool-chip interface; thereby a higher surface roughness occurs. ${ }^{18}$ To calculate the theoretical surface roughness, the abbreviated formula is expressed as follows:

$$
R_{\mathrm{a}}=\frac{f^{2}}{32 \cdot r}
$$

According to Equation (1), in order to improve the surface quality, the feed rate can be decreased or, alternatively, the nose radius of the cutting insert can be increased since the surface roughness is a function both the nose radius and feed rate. The results obtained from the experiments are similar to this formula. In the literature, it is pointed out that surface roughness is affected negatively by an increase in feed rate and in order to obtain the better surface quality, the feed rate is reduced usually in machining proceses. ${ }^{6,8,13}$ In present work, a similar result was detected when the surface roughness decreased with the increasing of feed rate.

According to Figure 4, the surface roughness showed a decreasing tendency with an increase in the cutting speed. An improvement in the surface quality was observed with the increasing cutting speed because the increasing temperature during the cutting process made the plastic deformation and the chip flow easier. ${ }^{6,18}$ Further, it is thought that because of a reduction in built-up edge (BUE) and built-up layer (BUL) formations, tool wear was affected positively, and so this situation gives rise to an improvement in the surface quality. ${ }^{6}$

During a manufacturing process, physical and chemical properties of the coolants allow a reduction in thermal/mechanical-based damages. When coolants are used efficiently, the dimensional accuracy and a better surface quality may occur; also, a longer life of the cutting tool may be obtained. Figure 4 shows a significant change in the surface-roughness values, depending on the use of different cooling methods. It can be seen that the surface roughness is minimum when using cryogenic 
cooling. This may be due to a lower cutting temperature, a lower adhesion between the cutting insert and the machined-workpiece surface and a lower tool-wear rate compared to dry and wet cooling conditions. ${ }^{19}$ In addition, a reduction in the surface roughness due to wet cooling was determined in comparison with dry machining.

\subsection{Signal-to-noise (S/N) analysis}

The surface roughness $\left(R_{\mathrm{a}}\right)$ was evaluated with an orthogonal array for each combination of the test parameters using the Taguchi technique and an optimization of the process parameters was achieved with signal-tonoise $(S / N)$ ratios. Here, the signal data includes the desired influence on the test results and the noise data includes the undesired influence on the test results. Therefore, the maximum $S / N$ ratio provides the optimum results. There are three different ways of calculating the $S / N$ ratios. These are the nominal-is-best, the smallerthe-better and the larger-the-better approaches. In the present study, the smaller-the-better option of the $S / N$ quality characteristic was utilized to obtain the best combination for the surface roughness with respect to the desired low $R_{\mathrm{a}}$. The smaller-the-better approach is expressed as follows: ${ }^{7}$

Smaller-the-better (minimize):

$$
\frac{S}{N_{R_{a}}}=-10 \log \left[\frac{1}{n} \sum_{r=1}^{n} o_{i}^{2}\right]
$$
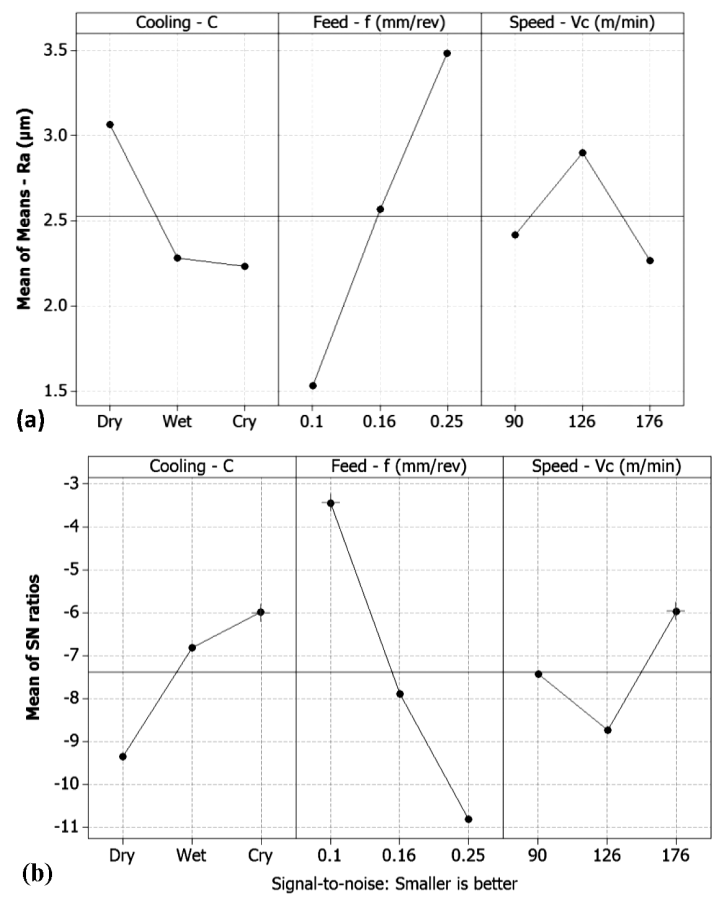

Figure 5: Main effect plots for: a) means and b) $S / N$ ratios Slika 5: Diagram učinka za: a) sredstva in b) razmerje $S / N$
In Equation (2), $o_{i}$ is the response of the output characteristic for the $r^{\text {th }}$ test and $n$ is the number of the outputs of the test.

The experimental results and their $S / N$ ratios were calculated using Equation (2) as given in Table 4. From this table, the mean surface roughness and the mean $S / N$ ratio were calculated as $2.53 \mu \mathrm{m}$ and $-7.39 \mathrm{~dB}$, respectively. The analysis of the process parameters like the cutting speed, feed rate and cooling condition was made using an $S / N$ response table obtained with the Taguchi method as seen in Table 5. The $S / N$ response table of the results gives the optimum points of the process parameters for the best surface roughness. Figure 5 was plotted to determine the optimum control factor of a machining parameter using the $S / N$ response table. As seen in Figure 5, for the highest $S / N$ ratio, the optimum parametric combination was found to be factor $A$ (level $3, S / N=-5.985 \mathrm{~dB}$, mean: $2.283 \mu \mathrm{m}$ ), factor $B$ (level 1 , $S / N=-3.450 \mathrm{~dB}$, mean: $1.533 \mu \mathrm{m}$ ) and factor $C$ (level 3, $S / N=-5.975 \mathrm{~dB}$, mean: $2.267 \mu \mathrm{m})$.

Under cryogenic cooling, the cutting speed was 176 $\mathrm{m} / \mathrm{min}$ and the feed rate was $0.1 \mathrm{~mm} / \mathrm{r}$.

Table 4: Experimental results and their $S / N$ values

Tabela 4: Rezultati eksperimentov in njihove $S / N$ vrednosti

\begin{tabular}{|c|c|c|c|c|c|}
\hline \multirow{2}{*}{$\begin{array}{c}\text { Test } \\
\text { no. }\end{array}$} & $\begin{array}{c}\text { A } \\
\text { Cooling } \\
\text { condition }\end{array}$ & $\begin{array}{c}\text { Control parameters } \\
\text { Feed rate } \\
f /(\mathrm{mm} / \mathrm{r})\end{array}$ & $\begin{array}{c}\text { C } \\
\text { Cutting } \\
\text { speed } \\
V_{\mathrm{c}} / \\
(\mathrm{m} / \mathrm{min})\end{array}$ & $\begin{array}{c}\text { Surface } \\
\text { roughness } \\
R_{\mathrm{a}} / \mu \mathrm{m}\end{array}$ & $\begin{array}{c}\text { Signal to } \\
\text { noise } \\
(S / N) / \mathrm{dB}\end{array}$ \\
\hline 1 & Dry & 0.1 & 90 & 1.90 & -5.5751 \\
\hline 2 & Dry & 0.16 & 126 & 3.55 & -11.0046 \\
\hline 3 & Dry & 0.25 & 176 & 3.75 & -11.4806 \\
\hline 4 & Wet & 0.1 & 126 & 1.65 & -4.3497 \\
\hline 5 & Wet & 0.16 & 176 & 2.00 & -6.0206 \\
\hline 6 & Wet & 0.25 & 90 & 3.20 & -10.1030 \\
\hline 7 & Cryogenic & 0.1 & 176 & 1.05 & -0.4238 \\
\hline 8 & Cryogenic & 0.16 & 90 & 2.15 & -6.6488 \\
\hline 9 & Cryogenic & 0.25 & 126 & 3.50 & -10.8814 \\
\hline
\end{tabular}

Table 5: Response table

Tabela 5: Tabela odgovorov

\begin{tabular}{|c|c|c|c|c|c|c|}
\hline \multirow{3}{*}{ Levels } & \multirow{2}{*}{\multicolumn{3}{|c|}{$\begin{array}{c}\text { Control factors } \\
S / N \text { ratios }\end{array}$}} & \multicolumn{3}{|c|}{ Control factors } \\
\hline & & & & \multicolumn{3}{|c|}{ Means } \\
\hline & A & B & $\mathrm{C}$ & A & B & B \\
\hline Level 1 & -9.353 & -3.450 & -7.442 & 3.067 & 1.533 & 2.417 \\
\hline Level 2 & -6.824 & -7.891 & -8.745 & 2.283 & 2.567 & 2.900 \\
\hline Level 3 & -5.985 & -10.822 & -5.975 & 2.283 & 3.483 & 2.267 \\
\hline Delta & 3.369 & 7.372 & 2.770 & 0.833 & 1.950 & 0.633 \\
\hline Rank & 2 & 1 & 3 & 2 & 1 & 3 \\
\hline
\end{tabular}

\subsection{Analysis of variance}

Analysis of variance (also known as ANOVA) is a statistical method and the significance of the machining parameters was identified with its help. The ANOVA analysis was performed with a $95 \%$ confidence level and 
$5 \%$ significance level. The $F$ values of the control factors indicated the significance of the control factors determined with the ANOVA analysis. The percentage contribution of each parameter is shown in the last column of the ANOVA table. The column shows the effect rates of the input parameters on the outputs. ${ }^{6}$

In the present work, the ANOVA results are given in Table 6 and, in addition, these results are graphically presented in Figure 6. The ANOVA results indicate that the cooling condition, the feed rate and the cutting speed influenced the surface roughness by $17 \%, 74.1 \%$ and $8.5 \%$, respectively. Therefore, the feed rate (factor $B$ ) is the most important factor affecting the surface roughness. According to Table 6, it can be said that the cooling condition, the feed rate and the cutting speed had a statistical and physical significance with regard to the surface roughness at the reliability level of $95 \%$ because their $P$ values are lower than 0.05 .

Table 6: ANOVA analysis

Tabela 6: Analiza ANOVA

\begin{tabular}{|c|c|c|c|c|c|c|}
\hline Factors & $\begin{array}{c}\text { Degree } \\
\text { of free- } \\
\text { dom }\end{array}$ & $\begin{array}{c}\text { Sum of } \\
\text { squares }\end{array}$ & $\begin{array}{c}\text { Mean of } \\
\text { squares }\end{array}$ & $\begin{array}{c}F \text { ratio, } \\
\alpha=0.05\end{array}$ & $P$ & $\begin{array}{c}\text { Contri- } \\
\text { bution } \\
(\%)\end{array}$ \\
\hline $\begin{array}{c}\text { Cooling } \\
\text { method }\end{array}$ & 2 & 1.3106 & 0.6553 & 48.14 & 0.020 & 17 \\
\hline $\begin{array}{c}\text { Feed } \\
\text { rate }\end{array}$ & 2 & 5.7106 & 2.8553 & 209.78 & 0.005 & 74.1 \\
\hline $\begin{array}{c}\text { Cutting } \\
\text { speed }\end{array}$ & 2 & 0.6572 & 0.3286 & 24.14 & 0.040 & 8.5 \\
\hline Error & 2 & 0.0272 & 0.0136 & & & 0.35 \\
\hline Total & 8 & 7.7056 & & & & 100 \\
\hline
\end{tabular}

\subsection{Regression analysis}

In many studies, a regression analysis was used to determine the relationship between the control factors and experimental results. In the present work, the control factors are the cutting speed $\left(V_{\mathrm{c}}\right)$, the feed rate $(f)$ and the cooling condition $(\mathrm{C})$ and the surface roughness $\left(R_{\mathrm{a}}\right)$ is the response. On the basis of the first-order model, a mathematical model was created using a regression analysis for predicting $R_{\mathrm{a}}$. The first-order model can be expressed with Equation (3):

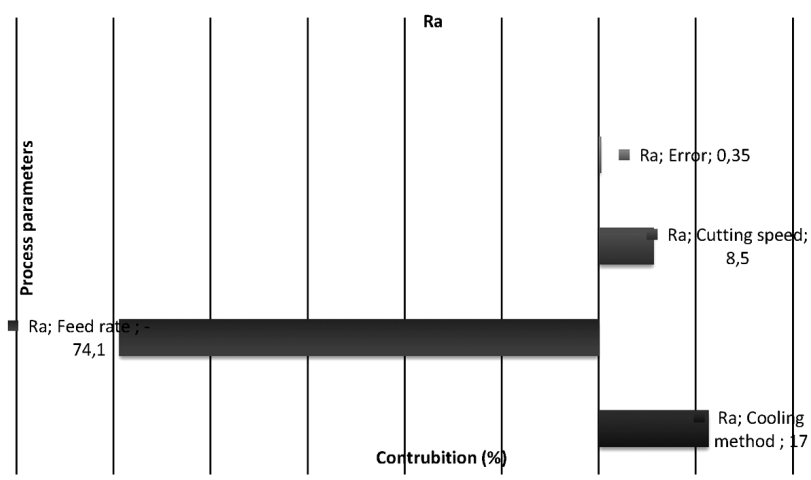

Figure 6: Graphical representation of the ANOVA results Slika 6: Grafičen prikaz rezultatov ANOVA

$$
y=\beta_{0}+\beta_{1} \cdot v_{1}+\beta_{2} \cdot v_{2}+\beta_{3} \cdot v_{3}
$$

In this equation, $y$ is the corresponding output, and $v_{1}$, $v_{2}$, and $v_{3}$ are the values of the variable. The term $\beta$ is the regression coefficient. The first-order model can be written as a function of the cooling condition $(C)$, the feed rate $(f)$ and the cutting speed $\left(V_{c}\right)$. The relationship between the output and the turning parameters from Equation (3) was adapted as given in following Equation (4):

$$
R_{\mathrm{a}_{\mathrm{pre}}}=\beta_{0}+\beta_{1} \cdot C+\beta_{2} \cdot f+\beta_{3} \cdot V_{\mathrm{c}}
$$

According to the above equations, a mathematical model for the surface roughness with coded values (Table 3) can be written in the following way:

$$
\begin{gathered}
R_{\mathrm{a}_{\mathrm{pec}}}=1.56111-0.416667 \cdot C+0.975 \cdot f-0.075 \cdot V_{\mathrm{c}} \\
R^{2}=87.98 \%
\end{gathered}
$$

The determination coefficient, expressed as $R^{2}$, shows the reliability of the predicted model. It was recommended that $R^{2}$ should be between 0.8 and $1 .^{20}$ In this study, the value of the determination coefficient is $R^{2}=$ 0.8798 and it is high enough, demonstrating a high significance of the predicted model. In order to evaluate the contents of the residual of the model, a graphical technique was employed. The sufficiency of the models was investigated by examining the residuals. The normal-probability plot of the residuals for the surface roughness is seen in Figure 7. It is seen that the residual rather appropriately tend towards a straight line, meaning that errors are normally delivered. This demonstrates that the predictive model is satisfactory.

\subsection{Determining the optimum surface roughness}

In the last phase of the Taguchi method, a verification experiment has to be made to check the reliability of the optimization. ${ }^{21}$ The verification experiment was conducted at the optimum levels of the variables determined as seen in Figure 5. $A_{3}-B_{1}-C_{3}$ and their values from this figure were employed to calculate the estimated optimum surface roughness. The equation for estimating the optimum result $\left(R_{\mathrm{a}_{\mathrm{opt}}}\right)$ was expressed as follows:

$$
R_{\mathrm{a}_{\text {opt }}}=\left(A_{3}-T_{\mathrm{R}_{\mathrm{a}}}\right)+\left(B_{1}-T_{\mathrm{R}_{\mathrm{a}}}\right)+\left(C_{3}-T_{\mathrm{R}_{\mathrm{a}}}\right)+T_{\mathrm{R}_{\mathrm{a}}}
$$

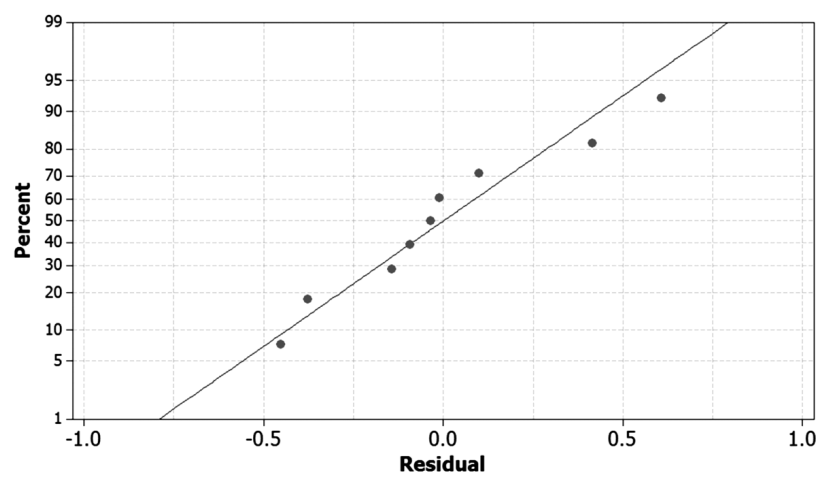

Figure 7: Normal-probability plot of the residuals Slika 7: Diagram normalne verjetnosti preostankov 
In Equation (6), $A_{3}, B_{1}$, and $C_{3}$ are the mean values of the surface roughness at the optimum level as seen in Table 5. $T_{R_{\mathrm{a}}}$ is the mean of all the $R_{\mathrm{a}}$ values obtained from the experimental results (Table 4). According to Equation (6), $R_{\mathrm{a}_{\text {opt }}}$ is $1.023 \mu \mathrm{m}$.

In order to verify the result of the estimated surface roughness, the confidence interval $(C I)$ was calculated using following equations: ${ }^{22}$

$$
\begin{gathered}
C I=\sqrt{F_{\alpha, 1, \mathrm{Ve}} \cdot V_{\mathrm{ep}} \cdot\left(\frac{1}{n_{\mathrm{eff}}}+\frac{1}{R}\right)} \\
n_{\mathrm{eff}}=\frac{N}{1+T_{\mathrm{dof}}}
\end{gathered}
$$

In Equation (7), $F_{\alpha, 1, V \mathrm{e}}$ is the $F$ ratio at the $95 \%$ confidence level, $\alpha$ is the significance level, $V_{\mathrm{e}}$ is the degree of freedom of the error, $V_{\text {ep }}$ is the error variance, $n_{\text {eff }}$ is the effective number of replications, $R$ is the number of replications for the verification test. In Equation (8), $\mathrm{N}$ is the total number of tests and $T_{\text {dof }}$ is the total main factor of the degree of freedom.

According to the $F$ test table, $F_{\alpha, 1,2}$ is 18.51 . Further, $V_{\text {ep }}=0.0136, R=3, \mathrm{~N}=9, T_{\text {dof }}=6$ and, according to Equation (8), $n_{\mathrm{eff}}$ is 1.285 . The confidence interval $(C I)$ is found to be 0.528 using Equations (7) and (8). The predicted optimum surface roughness with the $95 \%$ confidence interval is:

$\left[R_{\mathrm{a}_{\mathrm{opt}}}-C I\right]<R_{\mathrm{a}_{\mathrm{exp}}}<\left[R_{\mathrm{a}_{\mathrm{opt}}}+C I\right]$, i.e., $[1.023-0.528]<$ $1.05<[1.023+0.528]=0.702<1.05<1.551$.

The $R_{\text {aexp }}$, which was found with the experiments, was within the confidence interval limit. Therefore, the system optimization was successfully achieved using the Taguchi method at a significance level of 0.05 in the turning of the AISI 316Ti stainless steel under different cutting conditions.

\subsection{Experimental validation}

Verification experiments of the process parameters were performed for the best result and the predictive model at the optimum and at random points. Table 7 shows a comparison of the experimental results and the estimated results obtained with the Taguchi technique and mathematical model (Equation (5)). It was seen that the estimated results and the test results are quite close.

Table 7: Verification of the test results

Tabela 7: Preverjanje rezultatov preizkusov

\begin{tabular}{|c|c|c|c|c|c|c|}
\hline \multirow{2}{*}{ Level } & \multicolumn{2}{|c|}{ Taguchi technique } & \multicolumn{3}{c|}{ First-order model } \\
\cline { 2 - 7 } & Exp. & $\begin{array}{c}\text { Pre- } \\
\text { dicted }\end{array}$ & $\begin{array}{c}\text { Error } \\
(\%)\end{array}$ & Exp. & $\begin{array}{c}\text { Pre- } \\
\text { dicted }\end{array}$ & $\begin{array}{c}\text { Error } \\
(\%)\end{array}$ \\
\hline $\begin{array}{c}A_{3} B_{1} C_{3} \\
(\text { optimum })\end{array}$ & 1.05 & 1.023 & 1.8 & 1.05 & 1.06 & 0.9 \\
\hline $\begin{array}{c}A_{3} B_{2} C_{1} \\
(\text { random })\end{array}$ & 2.15 & 2.19 & 1.82 & 2.15 & 2.16 & 0.4 \\
\hline $\begin{array}{c}A_{2} B_{1} C_{2} \\
\text { (random) }\end{array}$ & 1.65 & 1.55 & 6.06 & 1.65 & 1.66 & 0.6 \\
\hline
\end{tabular}

The errors of the statistical analysis must be below $20 \%$ for the reliability of the analysis. ${ }^{20}$ Therefore, the results found in the verification experiment showed that the optimization was successful.

\section{CONCLUSIONS}

This study focused on the influences of the process parameters such as the cooling condition, the feed rate and the cutting speed on the surface roughness $\left(R_{\mathrm{a}}\right)$ in the turning of the AISI $316 \mathrm{Ti}$ stainless steel and an optimization was achieved on the basis of the Taguchi method. Cryogenic cooling using liquid nitrogen $\left(\mathrm{LN}_{2}\right)$ was applied from within a modified tool holder. The Taguchi $S / N$ ratio was utilized with the smaller-the-better approach to obtain the optimum values. An analysis of variance was performed to define the importance of the process parameters for the outputs. Based on the firstorder model, a mathematical model was created, namely $R_{\mathrm{a} \text { re }}$, using the regression analysis. The results obtained from this study can be summarized as follows:

The best parameter levels were found to be $A_{3}-B_{1}-C_{3}$ (i.e., cutting condition $=$ cryogenic cooling, feed rate $=$ $0.1 \mathrm{~mm} / \mathrm{r}$ and cutting speed $=176 \mathrm{~m} / \mathrm{min}$ ). Cryogenic cooling with $\mathrm{LN}_{2}$ and a modified tool holder provided a better performance than dry and wet conventional cooling in terms of the surface roughness and may be recommended for use in the turning of the AISI 316Ti stainless steel.

Although the surface quality decreased with an increase in the feed rate, it showed an improvement tendency with an increase in the cutting speed and with the use of the cryogenic cooling and wet (traditional) cooling.

Using ANOVA, it was found that the feed rate is the dominant factor affecting the surface roughness, with a fraction of $74.1 \%$, followed by the cooling method and the cutting speed. Further, it was seen that the cooling condition, the feed rate and the cutting speed had statistical and physical significance for the surface roughness, with a reliability level of $95 \%$.

The regression model showed a high correlation between the experimental and predicted values. Further, the normal-probability plot of the residuals for the surface roughness showed that the residuals quite appropriately tended to a straight line, meaning that errors were normally delivered. This proved that $R_{\text {apre }}$ was satisfactory and quite reliable. In addition, the value of the determination coefficient was high enough.

In the verification experiment, the measured values were within the $95 \%$ confidence interval $(C I)$.

Future work may deal with analyzing the effects of some cooling/lubrication methods like the minimumquantity lubrication (MQL), high-pressure cooling with a coolant, high-pressure cooling with compressed air, and external cryogenic cooling during the machining of the AISI 316Ti stainless steel. Further, other process para- 
meters like the cutting-tool geometry, depth of cut, CVD coated inserts, uncoated carbide inserts, nose radius, and chip-breaker geometry may be considered by the researchers to define their influences on the tool life and surface quality in future academic studies.

\section{REFERENCES}

${ }^{1}$ Y. Kayır, S. Aslan, A. Aytürk, Analyzing the effects of cutting tools geometry on the turning of AISI 316Ti stainless steel with Taguchi method, J. Fac. Eng. Arch. Gazi Univ., 28 (2013) 2, 363-372

${ }^{2}$ J. Brnic, G. Turkalj, M. Canadija, D. Lanc, AISI 316Ti (1.4571) steel - Mechanical, creep and fracture properties versus temperature, Journal of Constructional Steel Research, 67 (2011) 12, 1948-1952, doi:10.1016/j.jcsr.2011.06.011

${ }^{3}$ E. O. Ezugwu, Improvements in the machining of aero-engine alloys using self-propelled rotary tooling technique, Journal of Materials Processing Technology, 185 (2007) 1, 60-71, doi:10.1016/ j.jmatprotec.2006.03.112

${ }^{4}$ V. S. Sharma, M. Dogra, N. M. Suri, Cooling techniques for improved productivity in turning, Int. J. Mach. Tools Manufact., 49 (2009) 6, 435-453, doi:10.1016/j.ijmachtools.2008.12.010

${ }^{5}$ F. Pusavec, P. Krajnik, J. Kopac, Transition to sustainable production - Part I: application on machining technologies, J. Clean. Prod., 18 (2010) 2, 174-184, doi:10.1016/j.jclepro.2009.08.010

${ }^{6}$ M. Sarıkaya, A. Güllü, Multi-response optimization of MQL parameters using Taguchi-based GRA in turning of difficult-to-cut alloy Haynes 25, J. Clean. Prod., 91 (2015), 347-357, doi:10.1016/ j.jclepro.2014.12.020

${ }^{7}$ T. Kivak, Optimization of surface roughness and flank wear using the Taguchi method in milling of Hadfield steel with PVD and CVD coated inserts, Measurement, 50 (2014), 19-28, doi:10.1016/ j.measurement.2013.12.017

${ }^{8}$ M. Sarikaya, A. Gullu, Taguchi design and response surface methodology based analysis of machining parameters in CNC turning under MQL, Journal of Cleaner Production, 65 (2014), 604-616, doi:10.1016/j.jclepro.2013.08.040

${ }^{9}$ A. Kadirvel, P. Hariharan, Optimization of the die-sinking microEDM process for multiple performance characteristics using the Taguchi-based grey relational analysis, Mater. Tehnol., 48 (2014) 1, 27-32

${ }^{10}$ E. Kabakli, M. Bayramoğlu, N. Geren, Evaluation of the surface roughness and geometric accuracies in a drilling process using the Taguchi analysis, Mater. Tehnol., 48 (2014) 1, 91-98
${ }^{11}$ T. Kıvak, G. Samtaş, A. Çiçek, Taguchi method based optimisation of drilling parameters in drilling of AISI 316 steel with PVD monolayer and multilayer coated HSS drills, Measurement, 45 (2012) 6, 1547-1557, doi:10.1016/j.measurement.2012.02.022

${ }^{12}$ M. Sarıkaya, H. Dilipak, A. Gezgin, Optimization of the process parameters for surface roughness and tool life in face milling using the Taguchi analysis, Mater. Tehnol., 49 (2015) 1, 139-147

${ }^{13}$ İ. Asiltürk, H. Akkuş, Determining the effect of cutting parameters on surface roughness in hard turning using the Taguchi method, Measurement, 44 (2011) 9, 1697-1704, doi:10.1016/j.measurement. 2011.07.003

${ }^{14}$ M. A. Xavior, M. Adithan, Determining the influence of cutting fluids on tool wear and surface roughness during turning of AISI 304 austenitic stainless steel, Journal of Materials Processing Technology, 209 (2009) 2, 900-909, doi:10.1016/j.jmatprotec.2008.02.068

${ }^{15}$ I. Ciftci, Machining of austenitic stainless steels using CVD multilayer coated cemented carbide tools, Tribology International, 39 (2006) 6, 565-569, doi:10.1016/j.triboint.2005.05.005

${ }^{16}$ I. Korkut, M. Kasap, I. Ciftci, U. Seker, Determination of optimum cutting parameters during machining of AISI 304 austenitic stainless steel, Materials \& Design, 25 (2004) 4, 303-305, doi:10.1016/ j.matdes.2003.10.011

${ }^{17} \mathrm{Z}$. Tekıner, S. Yeşılyurt, Investigation of the cutting parameters depending on process sound during turning of AISI 304 austenitic stainless steel, Materials \& Design, 25 (2004) 6, 507-513, doi:10.1016/j.matdes.2003.12.011

${ }^{18}$ R. Suresh, S. Basavarajappa, V. N. Gaitonde, G. L. Samuel, Machinability investigations on hardened AISI 4340 steel using coated carbide insert, Int. J. Refract. Metals Hard Mat., 33 (2012), 75-86, doi:10.1016/j.ijrmhm.2012.02.019

${ }^{19}$ M. Dhananchezian, M. P. Kumar, Cryogenic turning of the Ti-6Al-4V alloy with modified cutting tool inserts, Cryogenics, 51 (2011) 1, 34-40, doi:10.1016/j.cryogenics.2010.10.011

${ }^{20}$ M. H. Cetin, B. Ozcelik, E. Kuram, E. Demirbas, Evaluation of vegetable based cutting fluids with extreme pressure and cutting parameters in turning of AISI 304L by Taguchi method, J. Clean. Prod., 19 (2011), 2049-2056, doi:10.1016/j.jclepro.2011.07.013

${ }^{21}$ N. Mandal, B. Doloi, B. Mondal, R. Das, Optimization of flank wear using Zirconia Toughened Alumina (ZTA) cutting tool: Taguchi method and regression analysis, Measurement, 44 (2011), 2149-2155, doi:10.1016/j.measurement.2011.07.022

${ }^{22}$ A. Dvivedi, P. Kumar, Surface quality evaluation in ultrasonic drilling through the Taguchi technique, Int. J. Adv. Manuf. Technol., 34 (2007), 131-140, doi:10.1007/s00170-006-0586-3 